\title{
The Cause of Preeclampsia
}

\section{Kazuo Maeda*}

Department of Obstetrics and Gynecology, Tottori University Medical School, Yonago, Japan

\section{Introduction}

The preeclampsia is a common maternal disorder in pregnancy, characterized by hypertension (pregnancy induced hypertension, $\mathrm{PIH}$ ) and associates proteinuria in 20 or a later week of pregnancy, which is also accompanied by enlarged hydatidiform mole pregnancy, and disappears after the birth. The presence of the fetus was proposed as its cause, while a hydatidiform mole has no fetus. Trophoblasts were considered to be the cause, but very active trophoblasts did not cause preeclampsia in the choriocarcinoma, while low invasion of trophoblasts to the uterine spiral artery was considered as its cause. Immunological phenomenon between the mother and fetus was denied as its cause. Very many metabolic changes were proposed as its cause, but they were partial phenomenon of preeclampsia. One hundred or more theories were proposed, but a review article in 2010 concluded that the cause of preeclampsia was unknown.

Kurotsu [1] reported the presence of sympathetic and the parasympathetic centers in the hypothalamus of rabbit 1949, and electrically stimulated the sympathetic center, resulting the increase of rabbit's blood pressure. The author of this article studied the electroencephalogram (EEG) of human eclampsia and preeclampsia in pregnancy, and tried to record deep hypothalamic EEG, where the sympathetic and parasympathetic centers of female non-pregnant rabbit were stimulated by using Kurotsu's electrode [1]. A hole was drilled on the coronal suture, $1 \mathrm{~mm}$ apart from the midline, and inserted the bipolar electrode for $15 \mathrm{~mm}$ deep for the stimulation of sympathetic center with an induction coil and $1.5 \mathrm{~V}$ dry battery for $10 \mathrm{sec}$. The blood pressure was measured at the central artery of the rabbit's ear before and after the electric stimulation, and urine was obtained inserting a thin catheter into rabbit's bladder, before and after the stimulation. Stimulated rabbit was excited; blood pressure elevated and proteinuria appeared at the same time in 3 out of 4 experimental rabbits. The parasympathetic center was stimulated further $1 \mathrm{~mm}$ outside of sympathetic for $10 \mathrm{sec}$, where no blood pressure change and no proteinuria were noted. The location of electrode was confirmed by the coronal section of rabbit's brain. In summary of experiments, electric stimulation of sympathetic center for $10 \mathrm{sec}$ provoked hypertension, and at the same, proteinuria by stimulation of sympathetic center [1]. Human preeclampsia would be caused by the stimulation of sympathetic hypothalamic center, which would be continuously stimulated by the enlarging uterus for 200 times of its non-pregnant volume. However, the route of conduction of the information of uterine enlargement to the hypothalamus was unknown for 60 years. Recently, 4 research papers reported the presence of nerves between the uterus and brain in rats and mice [2-5], which will play very important role in the formation of labor contractions of uterus [6].

Thus, the preeclampsia will be caused by the stimulation of hypothalamic sympathetic center by the enlarged uterus in the late pregnancy through the nerves innervated between the uterus and the brain.

\section{References}

1. Maeda K (1954) Electroencephalographic studies on the toxemias of pregnancy. J Jpn Soc Obstet Gynecol Jpn 6: 75-99.

2. Wiesel O, Toth IE, Boldokoi Z, Halasz B, Gerendai I, et al. (2004) Comparison of transsynaptic viral labeling of central nervous system structures from the uterine horn in virgin, pregnant, and lactating rats. Microsc Res Tech 63: 244252.

3. Yellon SM, Grushan LA, Rambau GM, Leshuga TJ, Kriby MA (2010) Pregnancyrelated changes in connections from the cervix to forebrain and hypothalamus in mice. Reproduction 140: 155-164.

4. Gnanamanickam GJ, Liewellyn-Smith IJ (2011) Innervation of the rat uterus at esterus: A study in full-thickness, immunoperoxidase-stained whole-mount preparations. J Comp Neurol 519: 621-643.

5. Poletini MO, McKee DT, Szawka RE, Bertram R, Helena CV et al. (2012) Cervical stimulation activates $\mathrm{A} 1$ and locus coeruleus neurons that project to the paraventricular nucleus of hypothalamus. Brain Res Bull 88: 566-573.

6. Maeda K (2013) Uterine contractions in normal labor developed by appositive feed-back and oscillation. J Health Med Informat.
*Corresponding author: Kazuo Maeda, Department of Obstetrics and Gynecology (Honorary Professor), Tottori University Medical School, Yonago, Japan, E-mail: maedak@mocha.ocn.ne.jp

Received October 14, 2013; Accepted October 15, 2013; Published October 19 2013

Citation: Maeda K (2014) The Cause of Preeclampsia. J Health Med Informat 5: e111. doi:10.4172/2157-7420.1000e111

Copyright: (c) 2014 Maeda K. This is an open-access article distributed under the terms of the Creative Commons Attribution License, which permits unrestricted use, distribution, and reproduction in any medium, provided the original author and source are credited. 